\title{
Structural Analysis of Relationship between Economic Activities and Water Pollution in Vietnam
}

\author{
Anh Hoang LE 1) $\quad$ Akihiro TOKAI 1) Yugo YAMAMOTO 2) \\ 1) Division of Sustainable Energy and Environmental Engineering, \\ Graduate School of Engineering, Osaka University \\ (2-1 Yamadaoka, Suita, Osaka, 565-0871, Japan) \\ 2) Department of Environmental System, Faculty of Systems Engineering, Wakayama University \\ (Sakaedani 930, Wakayama, 640-8510, Japan)
}

This paper employs Input-Output (IO) analysis framework to quantify not only sources but also causes of water pollution from Vietnamese economic activities. The study finds that in the year 2000, total TSS (Total Suspended Solids) and BOD (Biological Oxygen Demand) emissions from the economy are 356,419,325 $\mathrm{kg}$ and 43,756,010 kg, respectively. For TSS, the major emitter is "Basic Metal Industry" and the major inducers are "Construction" and "Basic Metal Industry". For BOD, the main dischargers are "Agriculture, Fishery and Forestry" and "Food, Beverage and Tobacco"; the major inducers are "Household" and "Export". The emission flows of each sector is further explored to draw an emission chain and to identify the key sectors of emissions. Depending on the analysis, a priority for emission reduction is suggested.

Key words : Vietnam economy, water pollution, input-output analysis, direct emission, induced emission, emission component

\section{I . Introduction}

Vietnam has gained significant achievements both economically and socially since "doimoi" reforms in the late 1980s (Que and Thanh, 2001). Such rapid development has had a considerable side effect on the country's environment in general and water quality in particular (The World Bank et al., 2002). Among environmental problems facing Vietnam, water pollution is the most important (GEF, 2002).

Conscious of the problem, the Vietnamese government has implemented various actions, from regulations to economic tools, to hopefully improve the current conditions and ensure a sustainable water supply. However, it seems that these efforts are not keeping pace with the rate of water quality degradation, considering the desired development and current institutional capacity. A report reviewing water sectors in Vietnam (KBR, 2008) indicated that "water quality deterioration, and the lack of positive actions to deal with it, is probably the greatest single environmental issue facing Vietnam". One of the constraints is the lack of a priority setting framework for suitable management actions (ICEM, 2007). The root cause is that little is understood about the way that the inter-relationship of economic activities, which are becoming a major source of pollution, characterizes wastewater emission.

The data and studies describing the effects of economic activities on water quality in Vietnam are rather limited. The Vietnam Environment Monitor (from 2002 to 2006) mainly described conditions of the natural water quality. 
Some studies have tackled the relationship between economic issues and pollution emissions. For example, Thong and Ngoc (2004) or Thanh (2009) based their work on small-scale surveys or case studies thus did not provide the broad picture of such relationships. In a broader project, the ICEM (2007) accessed national pollution emissions by quantifying the sources of emission of various pollutant types to land, water, and air media from the manufacturing sectors and sub-sectors with respect to geographic areas, and provided comparative indices to support authorities in setting pollution control priorities. Hung et al. (2008) also conducted descriptive industrial pollution analyses similar to the ICEM project; they further explored the effect of trade liberalization on industrial pollution at different structural levels. Initially, these studies were concerned only with manufacturing industries, and thus the true effect of the entire economic sectors that also include agriculture, service and final demands was not obtained. Next, they quantified the amount of pollution directly emitted by each sector or sub-sector. However, they failed to identify the causes and hidden factors contributing to such emissions from the entire economy in general and from each sector in particular. A further clarification would be useful for better priority setting, and to enhance the implementation of a better management program that could address supply chain management or restructure the economy to be more environmental friendly.

In this study, to overcome above limitation, an InputOutput (IO) analysis has been employed as a useful tool for analyzing the relationship between economic activities and the environment. An economic IO table provides a useful framework that accounts for interrelationships between sectors in the economy. By extending the table to include the appropriate environmental data, the technical relationships and flows between the sectors reflected in the model allow us to quantify the role of each sector in pollution emissions (Sanchez-Choliz and Duarte, 2005).

In Vietnam, the implication of IO modeling in environmental analysis has not been adequately recognized in research and in policy analysis because of the unpopularity of the IO table as well as the lack of comprehensive environmental data. To date, some

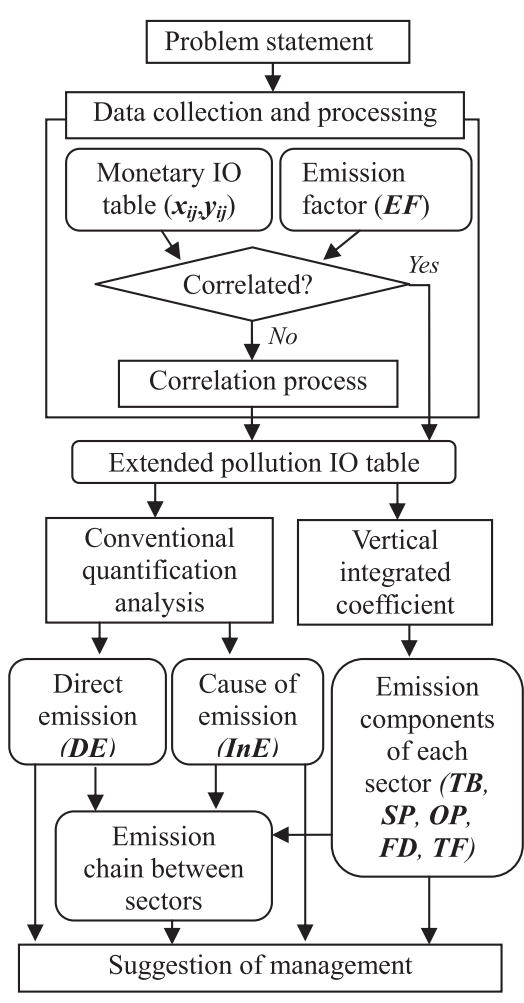

Fig. 1 Study flow.

図 -1 研究の手順

limited papers (Thanh et al., 2006; Trinh et al., 2008) dealt with water quality issues based on IO modeling. These papers demonstrated the usefulness of an interregional IO approach in environmental impact analysis. These studies also identified the source of the water pollution in specific regions (i.e., Hanoi, Hochiminh city). However, they did not indicate the causes of pollution and not have a purpose to explicit the pollution structure determined by the interrelationships between economic activities.

The weakness in pollution analysis and management, and the limited use of IO methodology observed in past researches in Vietnam indicates that this is one of the first studies that utilizes IO analysis for overcoming the common one-sided emission analysis and quantifying the role of Vietnam's economic sectors in water pollution both as a source and a cause of emission at the national level. The quantification of such roles reflects the effect that the interaction of economic activities has on pollution emissions. Furthermore, the assessment of 
emission components in each sector is conducted to determine the major factors influencing its emission characteristics and to establish material flow with respect to water pollution.

To achieve these objectives of this study, the following steps have been performed, as illustrated in Fig.1.

\section{II . Methodology}

\section{Source and Cause of Water Pollution Emissions}

The relationship between economic activities and water pollution is quantified by considering each economic sector as a source as well as a cause of emission. The source of emission, named as "direct emission $(D E)$," is the amount of emission directly emitted from production activities of an economic sector to meet all types of demand. Meanwhile, the cause of emission, named as "induced emission (InE)," is the amount of emission that an economic sector or a final demand induces other sectors or itself to emit for manufacturing products in demand by such manufacturer or consumers.

IO table together with emission factors $(E F \mathrm{~s})$ provide a simple framework calculating the above described types of emissions. Firstly, the emission from each transaction in IO table is calculated by directly multiplying all the elements in a row of each sector ( $i)$ with its corresponding k-pollutant type $E F_{i}^{k}$. The calculation can be simply performed by multiplying the diagonal matrix of $E F$ with the matrix of IO table, as shown in equation (1). To perform the process, it is necessary to arrange $E F$ s in Table 1 into diagonal elements of a diagonal matrix. The outcome of the operation is a matrix with the elements $\left(E_{i j}^{k}\right)$ as the amount of pollution $k$ emitted from manufacturing for each type of demand.

$$
\begin{aligned}
& {\left[E_{i j}^{k}\right]_{n \times m}=\left[E \hat{F}_{i}^{k}\right]_{n \times n} \times\left[x_{i j} \mid y_{i j}\right]_{n \times m}} \\
& =\left[\begin{array}{ccccc|ccc}
E F_{1}^{k} x_{11} & \cdots & E F_{1}^{k} x_{1 j} & \cdots & E F_{1}^{k} x_{1 n} & E F_{1}^{k} y_{1(n+1)} & \cdots & E F_{1}^{k} y_{1 m} \\
\vdots & \ddots & & & \vdots & \vdots & \ddots & \vdots \\
E F_{i}^{k} x_{i 1} & & E F_{i}^{k} x_{i j} & & E F_{i}^{k} x_{i n} & E F_{i}^{k} y_{i(n+1)} & \cdots & E F_{i}^{k} y_{i m} \\
\vdots & & & \ddots & \vdots & \vdots & \ddots & \vdots \\
E F_{n}^{k} x_{n 1} & \cdots & E F_{n}^{k} x_{n j} & \cdots & E F_{n}^{k} x_{n n} & E F_{n}^{k} y_{n(n+1)} & \cdots & E F_{n}^{k} y_{n m}
\end{array}\right]
\end{aligned}
$$

where ${ }^{\wedge}$ is symbol for diagonal matrix, $x_{i j}$ is intermediate demand, $y_{i j}$ is final demand, $\mid$ is used to distinguish the intermediate demand from the final demand in I-O data.

Then, the direct emission of sector $i\left(D E_{i}\right)$ and the induced emission of sector $j\left(\operatorname{In} D_{j}\right)$ are calculated as: $D E_{i}=\sum_{j=1}^{n} E F_{i}{ }^{k} x_{i j}+\sum_{j=n+1}^{m} E F_{i}{ }^{k} y_{i j}(2)$ and $\operatorname{In} E_{j}=\sum_{i=1}^{n} E F_{i}{ }^{k} x_{i j}$ or $\sum_{i=1}^{n} E F_{i}^{k} y_{i j}(3)$.

\section{Emission Components of Each Economic Sector}

The above analysis does not allow exploring emission components of each sector and emission flows between sectors. To cope with this, the method of "vertical integrated coefficient" proposed by Sanchez-Choliz and Duarte (2003) is employed. These authors partitioned pollution in each sector into five components of emission flows, including: True backward linkage $T B_{i}^{k}$ (total kpollution emitted by other sectors to produce input for sector i), Semi-own pollution $S_{i}{ }^{k}$ (total k-pollution generated by sector $\mathrm{i}$ to produce input for other sectors that is required to produce inputs that sector i purchases to create the final demand), Own pollution $O P_{i}^{k}$ (total kpollution emitted by sectors $i$ to produce input which is used by itself), Final demand pollution $F D_{k}^{i}$ (total kpollution directly emitted by manufacturing products for final demand) and True forward linkage $T F_{i}{ }^{k}$ (total kpollution directly emitted by manufacturing products for other intermediate demand).

While at the macro scale, the analytical approach in section 1 treats the final demand as an independent inducing sector, the method in this section, in the micro scale, integrated the final demand of each sector as a component of its induced emission. Thus, for each sector, the total emission induced from other sectors and itself for its processing activity and by its final demand is defined as an embedded emission ( $E B$ is a sum of $T B_{i}{ }^{k}$, $S P_{i}{ }^{k}, O P_{i}{ }^{k}$, and $\left.F D_{i}^{k}\right)$; the total emission emitted by a sector to meet all types of demand is similar and remains as a direct emission $(D E$, in this case, is equal to the sum of $S P_{i}^{k}, O P_{i}^{k}, F D_{i}^{k}$, and $\left.T F_{i}^{k}\right)$.

\section{Practical Application}

\section{Study Area and Target Emission}

The pollution analysis is carried out in Vietnam at national economic level. Vietnam is located on the east coast of the Indochina Peninsula bordering Cambodia 
and Laos in the west and China to the north. Since 2000 the Vietnam economy has prospered with an annual GDP rise around $7 \%$. The country's economy has shifted away from agriculture, forestry and fishery toward industrial activities. But contribution of agriculture to GDP still increases (GSO, 2009). This reflects the desire to make Vietnam into an industrialized country, but at the same time to ensure the national food security.

The country has become more dependent on water resources to meet the drinking water demand for the increasing population and urbanization and to meet the water supply demand for the increasing economic activities. However, water quality has drastically degraded with rapid industrialization and urbanization as a result of a poor management. A huge amount of polluted wastes is discharged to water bodies. Further industrial expansion will result in the acceleration of wastes entering the waters. Some river sections crossing dense city areas and industrial zones are heavily polluted. For example, the Thi Vai River, a lower reach of the Dongnai River Basin, has an area of about $10 \mathrm{~km}$ where the ecological system has been severely destroyed and water is unsuitable for any use (The World Bank et al., 2006).

In the study, TSS and BOD are two indices chosen for analysis. In terms of harmful effects, fertilizers and pesticides from agricultural activities, chemicals from industries, and heavy metals from mining activities pose a major risk to humans and the ecosystem. However, in Vietnam, a systematic monitoring of these hazardous parameters has not been conducted and very few data is available. Organic substances and suspended solids are main pollutants included in water quality reports in Vietnam. At low concentration, these pollutants may not threaten the ecosystem and human health; however, rivers or water bodies with high levels of these pollutions become dead zones.

\section{Data Source and Preparation}

To conduct IO analysis for water pollution caused by economic activities, two types of data are necessary: IO tables in monetary units (million VND: Million Vietnam Dong) and water pollutants $E F$ s.

\section{1) IO Table}

In Vietnam, a national IO table has been published by the General Statistic Office. According to Trinh et al. (2005), the first IO table was compiled in 1989 with 54 economic sectors. It was updated in 1996 and 2000 with 97 and 112 sectors, respectively. In addition, some regional and inter-relational IO tables have been developed for special applications, such as 48 sectors in Hochiminh city (HCMC) 2000 IO table by HCMC Provincial Statistical Office and 8 regions Inter-regional 2000 IO table by ALMEC Company; these tables are not yet publicly available.

In our analysis, the 2000 IO table (GSO, 2003) is used. The 2000 IO table includes 112 columns and rows of production sectors, 6 final demands columns, and 4 value-added rows for non-industrial input to production. Two types of product values are available for 2000 IO table including "price at final use" and "price of manufacture." The difference between them is that the value of the former considers the cost of infrastructure investment, transportation, and product taxes, while that of the latter does not include transportation costs. In our study, the IO table with the prices of manufacturer is used, because it relatively reflects a true technology of production in the existing economy structure. Up to the year 2000, because of insufficient data for import transaction, the national IO table makes no distinction between domestic and imported sources and is classified as a competitive-import type. Thus, the internalization of import and import tax into the value of products flowing into different demands is necessary before conducting the analysis. The process of adjustment has been discussed in detail in Nakamura and Kondo (2009). Because of this process, the emissions calculated on the basis of the output value are overestimated.

\section{2) Water pollutants EFs}

To complement IO table data, water pollutants $E F$ is defined as a parameter measuring the amount of emissions per unit of monetary output from an economic activity ( $\mathrm{kg} /$ million VND).

In Vietnam, this information has not been formally published and is unavailable for almost all sectors of the economy. Furthermore, annual statistical records of pollutants from discharging sources and to the environmental media are publicly unavailable. To overcome the above problem, data from two studies, Trinh et al. (2008) and Hettige et al. (1995) have been used. 
Trinh et al. (2008) obtained EFs for five pollutants (TSS, BOD, COD, $\mathrm{NH}_{4}-\mathrm{N}$, and Total $\mathrm{N}$ ) in his study. Because of insufficient information, data validation was not possible. The author's study covered two regions (HCMC and the rest of Vietnam); in our study, average values of the two regions are calculated and used as $E F \mathrm{~s}$ of the entire country. The calculation was done for the year 2000, and thus the units of the $E F$ s correspond to the 2000 Vietnamese currency. However, the data included only one 1-digit coding manufacturing industry that is an aggregation of all types of manufacturing industries in the economy. Therefore, a more detailed sectoral breakdown is expected in order to explore an in-depth structure of pollution generated from the manufacturing industries.

To meet the above expectation, Industrial Pollutant Projection System (IPPS) (Hettige et al., 1995) is utilized. This database was developed to help countries with or without insufficient industrial pollution data and has been used in many studies (A World Bank Country Study, 1994; Ferraz and Young, 1999; Oketola and Osibanjo, 2007; Pandey, 2005), even in Vietnam (Mani and Jha, 2006; ICEM, 2007). In the database, a sectoral $E F$ is estimated from environmental and economic data of about 200,000 U.S. factories and only manufacturing activities are considered. It includes three types of $E F \mathrm{~s}$ : output-based, value-added-based, and employmentbased. In this study, the output-based $E F$ is employed to complement the IO table data. For water media, IPPS accounts for BOD, TSS, Toxic Matters, and Metal. A sectoral classification is based on International Standard Industrial Classification version 2 (ISIC 2) with 2-, 3-, and 4-digit coding classification. In our analysis, 2-digit coding is employed because the manufacturing sectors in IO table are aggregated to 2 -digit coding levels. Furthermore, because IPPS unit of EF is "pound per million 1987 US dollars," it is necessary to convert them to "kg per million 2000 VND." The process of conversion and deflation is followed Mani and Jha (2006). IPPS has been used without validation because of the lack of an actual pollution inventory in Vietnam (Mani and Jha, 2006). Fortunately, ICEM (2007) conducted validation for IPPS in Vietnam's application. The Vietnamese monitored coefficients obtained from CTC Vietnam together with IPPS data were used for

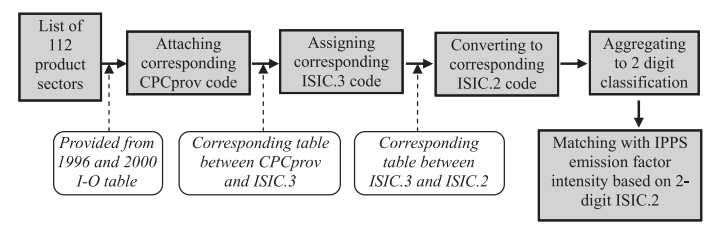

Fig. 2 Correlation process of IO table sectors and IPPS's EFs. 図-2 投入産出表七クターとIPPSの排出係数の相関処理

comparative analysis. At the sectoral level, the correlation is not high, but the differences are not statistically significant. Furthermore, Vietnamese data covers only limited sectors and may be collected using different methods; thus, IPPS is a preferred choice. ICEM (2007) also recognized that some industries such as seafood rapidly adopt new technologies, but many production technologies used in Vietnam in 2000 and even currently are similar to those used in the U.S. in late 1980s and early 1990s.

\section{3) Correlation processes of $I O$ table and EFs}

The Vietnamese IO table was constructed depending on the Provisional Central Product Classification system (CPCprov), whereas manufacturing activities in IPPS were classified according to ISIC2. Thus, reallocating products from the IO table to the corresponding manufactures that correlate with IPPS data is necessary.

Fig. 2 shows the correlation process. The initial step is coding all product sectors in the IO table depending on the CPCprov (GSO, 2000). UNSTATS (2009) provides the corresponding table between CPCprov and ISIC which helps to assign products to suitable manufactures. Because direct correspondence between CPCprov and ISIC 2 is not provided, ISIC version 3 is used as a connecting bridge. Some products are produced by several 4-digit coding industrial activities, but most of them belong to 3 - or 2-digit coding industries. The aggregation to the 2-digit coding levels is performed in order to fully cover all the associated products. For example, products from leather tanneries belong to 3231 , 3219, 3220, and 3232 4-digit coding manufacturers, and all these industries are aggregated into "Textile, Wearing Apparel, and Leather Industries" with the 2-digit code of 32. There are some exceptional products (e.g., electrical machinery and equipment) that are manufactured by both primary manufacturing activities and other secondary manufacturing activities. In the case for such products, it 
is assumed that the contribution of minor industries is not as significant as the main activities.

For the other sectors that do not belong to the manufacturing industries, the correlation is direct because EFs from Trinh et al. (2008) were arranged for use with the IO model.

The 2-digit manufacturing industries are available from IPPS for nine sectors, and data from Trinh et al. (2008) covers the other nine different sectors. Thus, the aggregation of 2000 IO table is from $112 \times 112$ product sectors to $18 \times 18$ corresponding economic activities. The method of consolidation in Excel is subsequently followed Nakamura and Kondo (2009).

The outcome is an extended pollution IO table shown in Table 1. Data of monetary value have been rounded up to billion for display, but the unit of million VND is used for calculation.

\section{IV . Results and Discussion}

\section{Source of Emission}

In each economic sector, products are distributed into different types of demand and correspond with certain amounts of generated emissions. Thus, emission from an economic activity or a source of emission is simply a sum of emissions emitted by producing products in the sector to serve all purposes required for operation of the economy. This is represented in equation (2). At a national level, emission load is commonly recorded using ton as a unit and rounded up to one or two decimal places. However, in this section, for comparing the results of the present study with that of Trinh et al. (2008)'s study, emission load is expressed using $\mathrm{kg}$ as a unit with zero decimal places; thus, we use $\mathrm{kg}$ as a final unit for emission load with zero decimal places. Fig. 3 indicates the amount of total emissions of TSS and BOD from each sector of the economy.

The "Basic Metal Industry" (sector 9), despite comprising only a small proportion of the total gross output ( $2 \%$, calculated from the IO table), is the largest source of TSS pollution $(276,631,558 \mathrm{~kg})$, accounting for $77.6 \%$ of the total emissions. The main reason for this emission to be larger than that emitted from other sectors is significantly owing to the higher TSS emission per unit of output. In fact, its $E F^{T S S}$ is 14 times higher than that of
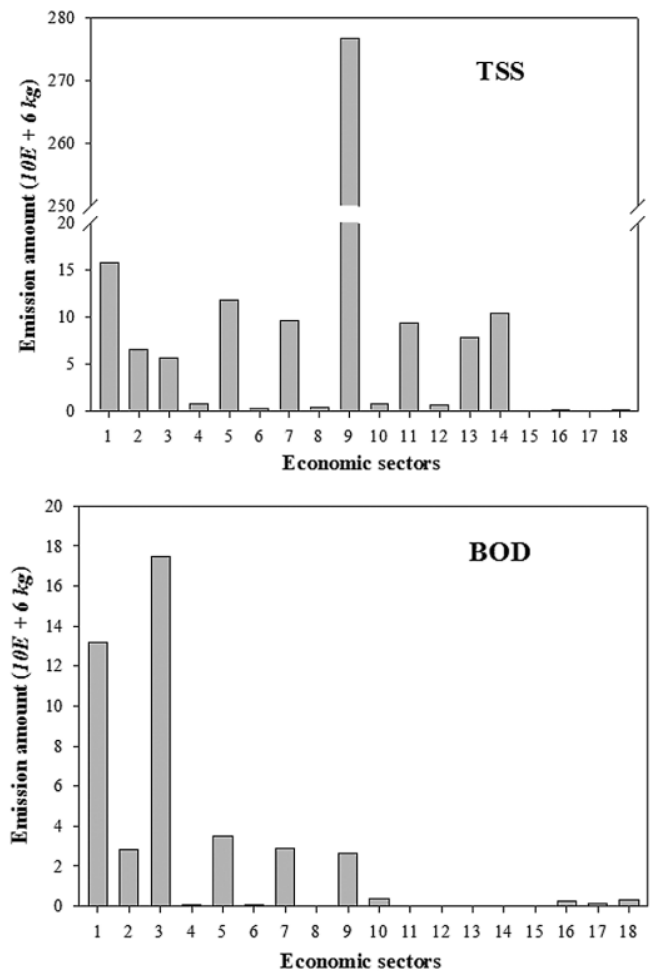

Fig. 3 Sources of emissions. 図 -3 排出の発生源

the second highest source (Table 1). The next major source of TSS is "Agriculture, Forestry and Fishery" (sector 1) $(15,810,405 \mathrm{~kg})$. Apart from the dominator of TSS emission (sector 9), "Manufacture of Paper and Paper Product, Printing, and Publishing" (sector 5), "Manufacture of Industrial Chemicals" (sector 7), and "Other Manufacturing Industries" (sector 11) are important TSS sources. TSS emission also encounters in two service activities: Construction (sector 13) and Trade (sector 14).

For BOD, sectors 1 and sector 3 (Food, Beverage and Tobacco) are the major BOD dischargers $(13,177,660 \mathrm{~kg}$ and $17,447,047 \mathrm{~kg}$, accounting for $30.1 \%$ and $39.9 \%$ of the total emission, respectively). In the middle range are three manufacturing industries (sector 5, 7, and 9) and "Mining and Quarrying" activity (sector 2). Emissions from the service sectors are minimal.

From our study, the total amount of TSS and BOD emissions by Vietnamese economic activities are $356,419,325 \mathrm{~kg}$ and $43,756,010 \mathrm{~kg}$, respectively. Comparing this to the estimation from Trinh et al. (2008)'s study 

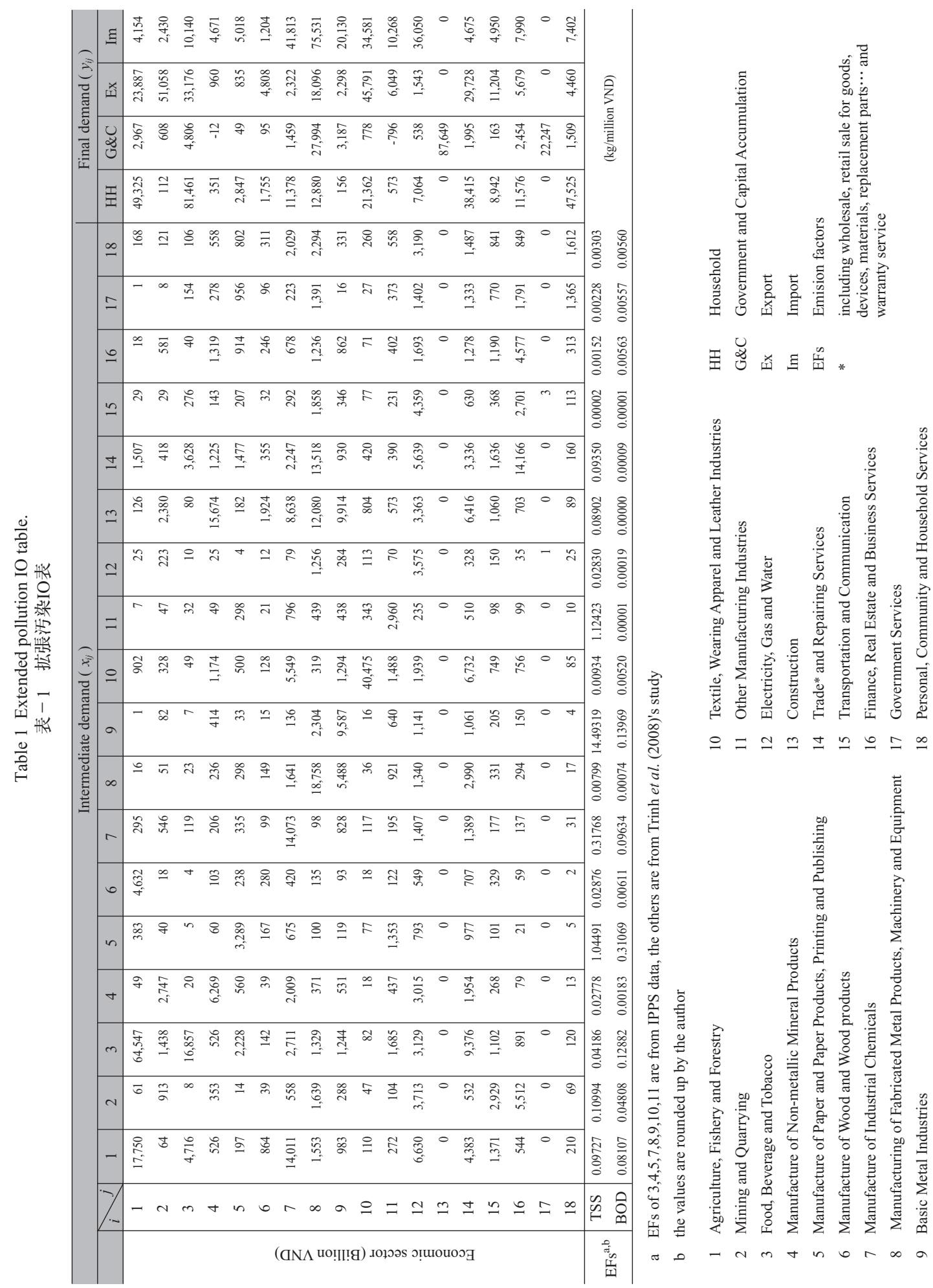

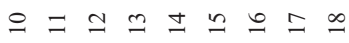

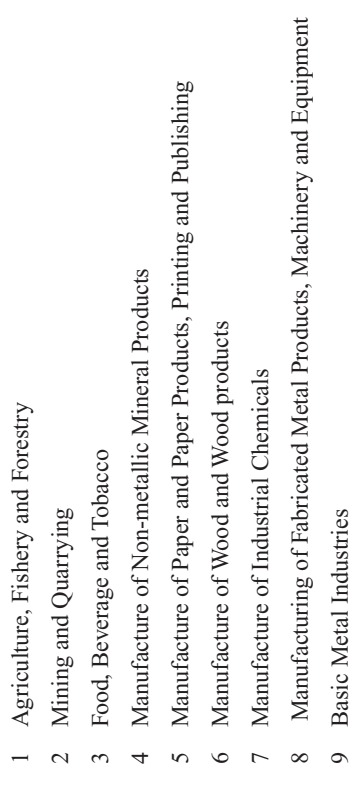


(71,391,036 $\mathrm{kg}$ and 44,155,063 $\mathrm{kg}$ for TSS and BOD, respectively), a large difference is observed for TSS emissions (+0.8), while BOD emissions are slightly different $(-0.009)$. The difference in each type of pollutant is calculated as [("Our study's value" - "Trinh et al. (2008) study's value”)/“Our study's value"]. The large dissimilarity in TSS emissions originates from the large difference in the $E F^{T S S}$ used in the two studies. The average $E F^{T S S}$ of manufacturing industries in our study is $1.8995 \mathrm{~kg} / \mathrm{million}$ VND. This is 30 times higher than that in the Trinh et al. (2008) $(0.0626 \mathrm{~kg} / \mathrm{million} \mathrm{VND})$. Furthermore, when the EFTSS of sector $9(14.4932 \mathrm{~kg} /$ million VND) is replaced with the $E F^{T S S}$ of sector 11 (1.12423 kg/million VND), which is the second highest source, the total TSS emissions become $101,245,989 \mathrm{~kg}$, thereby reducing the difference to only +0.29 . Therefore, in our study, to explain the difference in TSS emissions a high value of $E F^{T S S}$ in sector 9 from IPPS is utilized.

\section{Cause of Emissions}

Each economic sector requires products from other sectors or itself for its process (intermediate demand) or its final consumption (final demand), consequently incurring associated emissions from other sectors and itself. Thus, induction of emissions of an activity or the cause of emissions is the amount of emissions incurred from other sectors or itself to create products to meet its demand. This is presented in equation (3). Fig.4 shows the contribution of each sector to a total emission as a cause of pollution.

Sector 13 induces the highest TSS emissions (19.1\% of the total), followed by sector 9 accounting for $17.8 \%$. The reason is that sector 13 purchases $\sim 4,508,254$ million VND valued products, the third largest input, created by sector 9. The associated emission amount is responsible for $24 \%$ of emission from sector 9 (the biggest share) and accounts for $96 \%$ of its total $\operatorname{InE}$. For sector 9 , it consumes $22.8 \%$ of its own products (the second biggest amount after sector 13), accounting for $99.5 \%$ of its $I n E$. At the final demand end, export activities are the main driver of TSS emission, $15.3 \%$ comparing to $4.5 \%$ of Household $(\mathrm{HH})$, and $8.3 \%$ of others. It can be seen that production activities of the economic sectors are the major induction of TSS emissions compared to final demand ( $71.9 \%$ vs. $28.1 \%$, respectively).

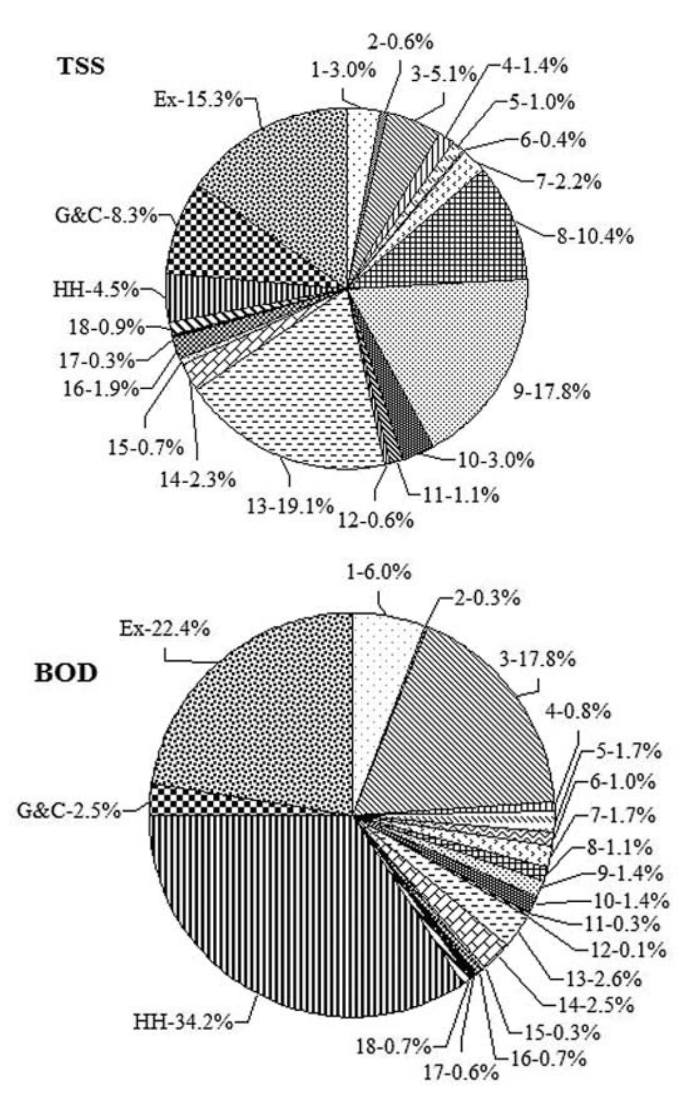

Fig. 4 Induction of emissions. 図一 4 誘発された排出量

Contrary to TSS inducers, the final demand is the main driving force for BOD, which accounts for $59.1 \%$ of the total InE of BOD. The leading emissions driver is $\mathrm{HH}$, accounting for $34.2 \%$ of the total $\operatorname{InE}$, followed by the "Export" (Ex) with $22.4 \% .50 \%$ and $24.5 \%$ of emissions from sector 3 (the largest BOD source) are induced by $\mathrm{HH}$ and Ex, respectively. From the production side, the processes of sector 3 induce $17.8 \%$ of the total emissions; $65.4 \%$ and $25.4 \%$ of its $\operatorname{In} E$ are from sector 1 and itself, respectively.

\section{Emission Components of Each Sector}

The values of emission components (True backward $(T B)$, Semi-own pollution $(S P)$, Own pollution $(O P)$, Final demand pollution $(F D)$ and True forward $(T F)$ ), embedded pollution $(E B)$ and direct pollution $(D E)$ for each sector are given in Table 2 .

For each sector, by plotting the percentage of $T F$ over its $D E$ against the percentage of $T B$ over its $E B$ of each 
Table 2 Emission components of 18 economic sectors (in tons). 表－2 18の経済セクターの排出成分

\begin{tabular}{|c|c|c|c|c|c|c|c|c|c|c|c|c|c|c|c|c|c|c|c|c|}
\hline & Sector & 1 & 2 & 3 & 4 & 5 & 6 & 7 & 8 & 9 & 10 & 11 & 12 & 13 & 14 & 15 & 16 & 17 & 18 & Total \\
\hline \multirow{7}{*}{ TSS } & $E B$ & $16,884.5$ & $10,426.1$ & $35,472.5$ & 482.8 & $4,308.6$ & $1,804.1$ & $5,454.1$ & $36,146.5$ & $72,145.3$ & $17,076.6$ & $10,863.3$ & 797.7 & $108,155.7$ & $19,326.7$ & $3,279.0$ & $4,380.0$ & $3,082.7$ & $6,333.2$ & $356,419.3$ \\
\hline & $D E$ & $15,810.4$ & $6,528.4$ & $5,669.4$ & 715.7 & $11,752.4$ & 298.4 & $9,565.8$ & 352.7 & $276,631.6$ & 714.5 & $9,366.0$ & 571.8 & $7,802.4$ & $10,367.9$ & 0.6 & 68.5 & 50.7 & 152.3 & $356,419.4$ \\
\hline & $T B$ & $8,599.0$ & $4,670.6$ & $30,100.4$ & 439.2 & 665.6 & $1,617.4$ & $2,538.1$ & $35,888.7$ & 110.5 & $16,377.1$ & $3,632.0$ & 673.0 & $100,353.2$ & $12,694.3$ & $3,278.6$ & $4,351.0$ & $3,032.0$ & $6,187.9$ & $235,208.6$ \\
\hline & $S P$ & 145.0 & 12.5 & 89.6 & 0.1 & 8.9 & 0.6 & 6.1 & 1.4 & 236.8 & 0.3 & 9.6 & 0.2 & 0.0 & 91.3 & 0.0 & 0.2 & 0.0 & 0.0 & 602.5 \\
\hline & $O P$ & 878.5 & 68.5 & 608.3 & 8.9 & 718.8 & 4.1 & 544.1 & 28.1 & $16,453.0$ & 174.0 & 467.3 & 7.5 & 0.0 & 188.7 & 0.0 & 2.4 & 0.0 & 4.0 & $20,156.4$ \\
\hline & $F D$ & $7,262.0$ & $5,674.5$ & $4,674.1$ & 34.6 & $2,915.3$ & 182.1 & $2,365.8$ & 228.4 & $55,345.1$ & 525.1 & $6,754.4$ & 117.0 & $7,802.4$ & $6,352.4$ & 0.4 & 26.4 & 50.7 & 141.2 & $100,451.8$ \\
\hline & $T F$ & $7,524.9$ & 772.9 & 297.4 & 672.1 & $8,109.4$ & 111.6 & $6,649.8$ & 94.8 & $204,596.7$ & 15.0 & $2,134.8$ & 447.0 & 0.0 & $3,735.5$ & 0.2 & 39.5 & 0.0 & 7.0 & $235,208.7$ \\
\hline \multirow{8}{*}{ BOD } & & & & & & & & & & & & & & & & & & & & \\
\hline & $E B$ & 757.8 & $2,683.0$ & $23,308.5$ & 31.0 & 117.1 & 402.0 & 965.3 & 539.2 & 708.4 & $1,181.3$ & 143.1 & 13.5 & $2,077.1$ & $1,136.4$ & 145.6 & 304.1 & 516.0 & 726.8 & $43,756.0$ \\
\hline & $D E$ & $13,177.7$ & $2,855.1$ & $17,447.0$ & 47.2 & $3,494.4$ & 63.4 & $2,900.9$ & 32.9 & $2,666.2$ & 397.6 & 0.0 & 3.8 & 0.0 & 10.0 & 0.3 & 253.6 & 123.9 & 281.9 & $43,756.0$ \\
\hline & $T B$ & 852.0 & 165.9 & $6,776.6$ & 28.1 & 34.0 & 362.3 & 81.0 & 515.1 & 14.2 & 792.0 & 143.0 & 12.6 & $2,077.1$ & $1,130.1$ & 145.4 & 196.7 & 392.1 & 457.9 & $14,176.0$ \\
\hline & $S P$ & 120.9 & 5.5 & 275.7 & 0.0 & 2.6 & 0.1 & 1.9 & 0.1 & 2.3 & 0.2 & 0.0 & 0.0 & 0.0 & 0.1 & 0.0 & 0.8 & 0.0 & 0.1 & 410.2 \\
\hline & $O P$ & 732.2 & 30.0 & $1,872.0$ & 0.6 & 213.7 & 0.9 & 165.0 & 2.6 & 158.6 & 96.9 & 0.0 & 0.1 & 0.0 & 0.2 & 0.0 & 9.1 & 0.0 & 7.4 & $3,289.1$ \\
\hline & $F D$ & $6,052.7$ & $2,481.7$ & $14,384.1$ & 2.3 & 866.8 & 38.7 & 717.5 & 21.3 & 533.4 & 292.3 & 0.0 & 0.8 & 0.0 & 6.1 & 0.2 & 97.6 & 123.9 & 261.4 & $25,880.7$ \\
\hline & $T F$ & $6,271.9$ & 338.0 & 915.2 & 44.3 & $2,411.2$ & 23.7 & $2,016.6$ & 8.8 & $1,971.9$ & 8.3 & 0.0 & 3.0 & 0.0 & 3.6 & 0.1 & 146.2 & 0.0 & 13.0 & $14,176.0$ \\
\hline
\end{tabular}

sector (Fig.5), all economic sectors can be classified regarding the characteristics for major emission flows between sectors.

It can be see that the share of $T F / D E$ for all sectors is similar for both types of pollution, but the share of $T B / E B$ for each sector changes according to the emission type. In fact, the former value is determined by the share of products going to different demands, which is independent of $E F$. On the other hand, the latter value is dependent on the supplying sectors that have dissimilar characteristics of emissions for each type of pollution.

In general, sectors with similar patterns of emission flows are clustered into one in the four regions divided by the horizontal line of $50 \% T F / D E$ and the vertical line of $50 \% T B / E B$.

Sectors above the $50 \% T F / D E$ line mainly release pollution associated with the creation of products for other sectors' demand. Among them, further divisions can be observed. For both types of pollution, sectors 5, 7, and 9 belong to region (I), which is characterized by low $T B / E B$. These sectors have a lower share of induced emission from other sectors. However, sectors 5 and sector 7 show the tendency of more induced TSS than BOD. On the contrary, region II, which in addition has a high percentage of $T B / E B$, is comprised of three sectors: 4,12 , and 16 . They induce emissions from other sectors and are also to be induced by others.
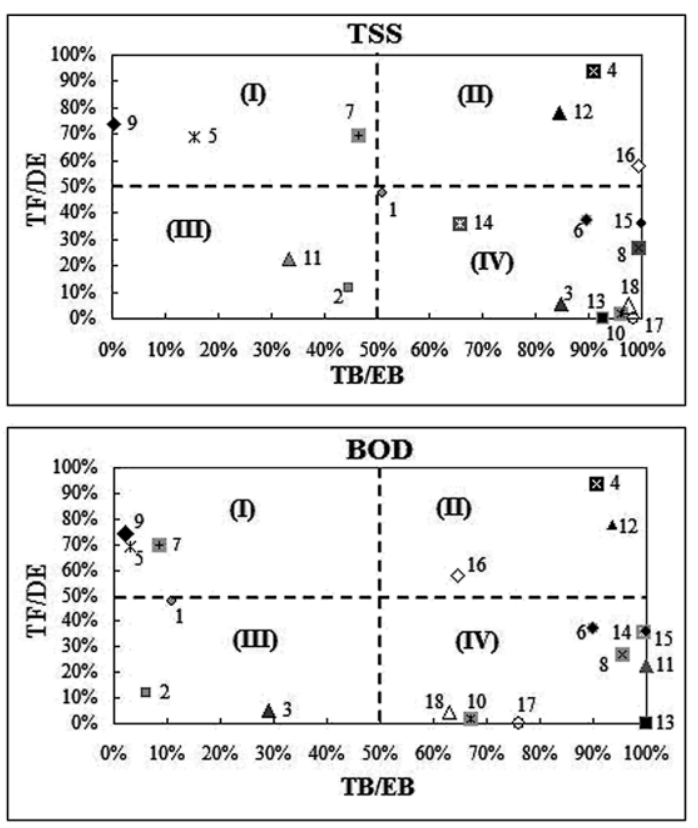

Fig. 5 Classification of emission flows. 図 -5 排出量の分類

Sectors under the $50 \% T F / D E$ line generally have their $D E$ caused by its final demand. Two manufacturing industries (sector 6 and sector 10) and most service activities and are located in region IV for both types of pollution. This means they cause emissions from other sectors for their operation. Region III includes sectors 
that have a low dependence on other sectors for their final demand (sector 2).

There are several interesting cases showing the change of emission patterns (sectors 1, 3, and 11). Sector 1 shows the balance of direct and induced TSS emissions. However, BOD is less induced because its input providers have a low $E F^{B O D}$. Sector 3 is a low TSS discharger, but depends on heavy TSS releasing sectors. For BOD, its low share of $T B$ is a result of its large $E B$, and its final demand hiding the flow of BOD from other sectors. Sector 11 clearly depends on other sectors with high TSS but low BOD emissions.

In terms of the internal effect (reflecting from value of $O P$ ) in relation with $E B$, the sectors 9 and 7 are considered that account for $22.8 \%$ and $10.1 \%$ for TSS, and $22.5 \%$ and $17.5 \%$ for BOD, respectively. On the other hand, the internal demand of sectors 3 and 10 accounts for $10.7 \%$ and $24.4 \%$, respectively, in their $D E$.

Although most service activities fall into region IV, in terms of quantity, except the $E B$ for TSS of sector 13, all the remaining service activities have $E B$ s of both TSS and BOD lower than $5.5 \%$. It is interesting that the service sectors do not clearly appear to be the main drivers of pollution as expected, and this differs from the analysis of Sanchez-Choliz and Duarte (2005) for a Spain case.

Table 2 shows low emissions for mixed effects in both pollutants. Hence, the $S P$ is negligible. This characteristic is similar to the case of Sanchez-Choliz and Duarte (2005).

In order to explore the relationship between the emission flows in different sectors, it is useful to draw the emission chains for each sector in relation to other sectors. For a sector, this includes components of $T B_{i}{ }^{k}$, $T F_{i}^{k}$ from and to other sectors, and its five total emission components. Their values are given Table 2 showing emission profile of each sector. In this paper, we draw the emission chain between sectors 9 and 13, major sources and causes of TSS, and between sector 1, sector 3 , and $\mathrm{HH}$, major sources and causes of BOD to illustrate

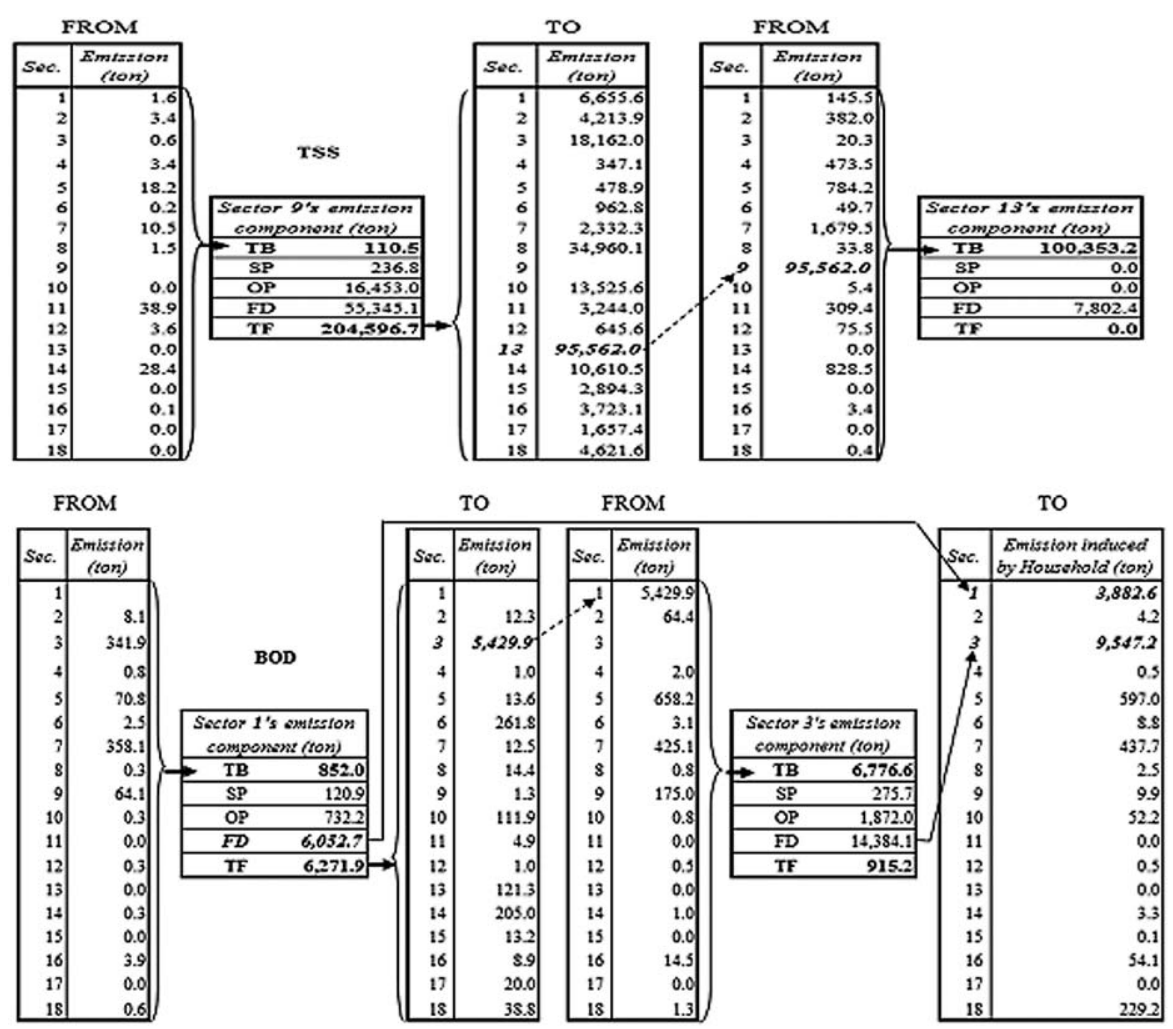

Fig. 6 A chain of emissions of major sources and causes. 図 -6 主要発生源と原因からの排出連鎖 
the relationship of these major sectors in pollution emission (Fig.6).

It is clearly that for TSS sector 13 is a main inducer of emission from sector 9, and "final demand" is also an important cause for the emission of sector 9. For BOD, sector 3 induces most of the emission flowing to others of sector 1, and the majority of the emissions caused by "final demand" end up in HH consumption.

\section{Emission Reduction Priority}

The analysis of $D E$ and $I n E$ helps to identify management priorities. With regard to emission sources of TSS, the focus should be on sector 9, however four other important sources are sectors 1, 5, 14, and 7. For BOD, five sectors were considered: sector 3, 1, 5, 2, and 7, which are ordered from largest to smallest amount of emissions. The best way to decrease emissions from sources is to lower the value of $E F$ or output products. The selection for each sector is based on its degree of dirtiness and productivity, reflected through $E F$ and total output products, respectively. This can be approached in many ways, e.g., implementation of cleaner technology or improvement of end-of-pipe wastewater treatment system. In addition, decreased emissions can be achieved by managing the causes. On the side of manufacturers, the sectors needing to reduce TSS are sectors 13 and 9, while sector 3 needs to reduce BOD. The actions could lead to less dependence on polluted suppliers thereby by improving the process efficiency or shifting to an unpolluted input. At the final demand, export should be toward less polluted TSS sectors. To reduce BOD emission, household consumption should be managed. A framework to facilitate the use of more environmental friendly product should be encouraged. In addition, reducing consumption would also help.

Fig. 5 provides general directions for emission reduction. As per these directions, sectors in IV region are suitable for considering demand management for reducing emission of their input providers, and regions I and II or providers are suitable for employing abatement technology to lower the emissions. Region III could be managed by either demand management or abatement or both because its direct emission closely associates with the final demand.

\section{V . CONCLUSION}

This research can be considered the initial study trying to investigate water pollution generated from industrial sectors of the Vietnamese economy with regards to direct emissions, induced emissions, and flow of emissions between sectors. The methodology has taken advantage of the availability of IO tables in Vietnam. It creates an easy framework for managers to understand the nature of pollution generated by the Vietnamese economy and to grasp the major factors inside the economy contributing to the emission, not only as polluters but also as inducers. With this information, priorities can be determined appropriately. Results are summarized as follows:

(1) The emission patterns of water pollution from the Vietnam economy are characterized by the nature of particular sectors. "Basic Metal Industry" is a major polluter of TSS, while "Food, Beverage and Tobacco" and "Agriculture, Fishery and Forestry" are the main BOD dischargers.

(2) The importance of IO framework is to identify the sectors inducing emissions. The inducing forces from economy systems in both case is final demand. However, there are also dissimilarities between the two types of pollution. BOD is strongly induced by final demand, but TSS is relatively equally induced by manufacturing process of "Construction" and "Basic Metal Industry," and "final demand."

(3) In the Vietnamese economy, there is a direct link between sectors with major direct emissions and sectors with major induced emissions. Service activities, except for sector 13 that acts as one of the major TSS inducers, play an insignificant role as inducer.

(4) The research has overcome the difficulty of insufficient emission data by employing IPPS. The results show a high correlation for $\mathrm{BOD}$, but a huge divergence for TSS. Therefore, IPPS should be used with care in future. A review of major polluters identified with IPPS data should be conducted practically.

The results, even with some uncertainties, provide a general picture of pollution from economic activities, which could help direct further studies. For example, the "Agricultural, Fishery and Forestry" sector should be 
further studied because of its important role in wastewater emissions, and further studies on "Basic Metal Industry" is needed to reduce its emissions.

\section{Acknowledgement}

We thank the Ministry of Education, Culture, Sports, Science and Technology (MEXT), Japan, for providing a scholarship to study and conduct this research.

\section{Reference}

A World Bank Country Study. 1994. Indonesia: Environment and Development. The World Bank: Washington, DC; 245246.

Ferraz C, Young CEF. 1999. Trade Liberalization and Industrial Pollution in Brazil. United Nations Publications: Santiago; 8-9.

GEF (Global Environmental Forum). 2002. Overseas environmental measures of Japanese companies (Vietnam). http://www.env.go.jp/earth/coop/oemjc/viet/e/contents.html. (accessed 2010/01/16).

GSO (General Statistical Office). 2000. Input-Output: IO of Vietnam Year 1998. Statistical Publishing House: Hanoi; 298321.

GSO (General Statistical Office). 2003. Input-Output: IO of Vietnam Year 2000. Statistical Publishing House: Hanoi; 142246.

GSO (General Statistical Office). 2009. Statistical Yearbook of Vietnam 2008. Statistical Publishing House: Hanoi; 71-73.

Hettige H, Martin P, Singh M, Wheeler D. 1995. The Industrial Pollution Projection System. Policy Research Working Paper WPS1431; E1-E6 and 2digtot.wk1 (file).

http://go.worldbank.org/TKBAVCDK10.(accessed 2009/09/27).

Hung PT, Tuan BA, Chinh NT. 2008. The impact of trade liberalization on industrial pollution: empirical evidence from Vietnam. http://www.idrc.ca/uploads/user-S/12483164701 Pham_Hung_Thai_2008_RR5.pdf. (accessed 2010/01/30).

ICEM (International Center for Environmental Management). 2007. Analysis of pollution from manufacturing sectors in Vietnam. Technical Report for the World Bank in Partnership with MONRE and MOI; 15-18 and 66-67.

http://www.icem.com.au/documents/envassessment/wb_cea/ WB_CEA.pdf. (accessed 2009/09/30).

KBR (Kellogg Brown \& Root Pty Ltd). 2008. ADB TA 4903-VIE watersector review project: issues and options. Working Paper Prepared for The Office of the National Water Resources Council on Behalf of the Government of Vietnam and a Number of International Development Partners Led by the Asian Development Bank; 16.

Mani M, Jha S. 2006. Trade liberalization and the environment in Vietnam. Policy Research Working Paper WPS3879; 16-17 and 30. http://go.worldbank.org/J62ASJBSR0. (accessed 2009/10/15).

Nakamura S, Kondo Y. 2009. Waste Input-Output analysis: concepts and application to industrial ecology. In Volume 26 of Eco-Efficiency in Industry and Science, Tukker A (ed).
Springer: Netherlands; $67-71$ and 114-118.

Oketola AA, Osibanjo O. 2007. Estimating sectoral pollution load in Lagos by Industrial Pollution Projection System (IPPS). Science of the Total Environment 377: 125-141. DOI:10.1016/j.scitotenv.2006.12.054.

Pandey R. 2005. Estimating sectoral and geographical industrial pollution inventories in India: implications for using effluent charge versus regulation. Journal of Development Studies 41: 33-61. DOI: 10.1080/0022038042000276563.

Que TT, Thanh VT. 2001. Vietnam: achievements and challenges. Social Watch Annual Report 2001. http://www.socialwatch.org/sites/default/files/pdf/en/vietna m2001_eng.pdf. (accessed 2010/01/27).

Sanchez-Choliz J, Duarte R. 2003. Analyzing pollution by way of vertically integrated coefficients, with an application to the water sector in Aragon. Cambridge Journal of Economics 27: 433-448. DOI: 10.1093/cje/27.3.433.

Sanchez-Choliz J, Duarte R. 2005. Water pollution in the Spanish economy: analysis of sensitivity to production and environmental constraints. Ecological Economics 53: 325338. DOI:10.1016/j.ecolecon. 2004.09.013.

Thanh LH. 2009. Assessing the impacts of environmental regulations on the food processing industry in Vietnam. http://ideas.repec.org/p/eep/report/rr2010032.html. (accessed 2010/01/30).

Thanh LH, Trinh B, Hung DM. 2006. Measuring the environmental impact of regional economic growth: an interregional Input-Output approach. In Business Environment and Policies of Hanoi, Ohno K, Thuong NV (ed). Publishing House of Social Labor: Hanoi; 193-223.

The World Bank, The National Environmental Agency, The Danish Agency for International Development. 2002. Vietnam Environmental Monitor 2002; 20-22.

http://siteresources.worldbank.org/INTEASTASIAPACIFIC/ Resources/VN-Monitor-02.pdf. (accessed 2010/01/21).

The World Bank, The Ministry of Environment and Natural Resources, The Danish International Development Assistance. 2006. Vietnam Environmental Monitor 2006Water Quality in Vietnam with a Focus on the Cau, Nhue-Day and Dongnai River Basins; xii.

http://go.worldbank.org/VHNN3QCOAO. (accessed 2010/01/21).

Thong LQ, Ngoc NA. 2004. Incentives for wastewater management in industrial estates in selected provinces of Vietnam. http://ideas.repec.org/p/eep/report/rr2004084.html. (accessed 2010/01/30).

Trinh B, Secretario FT, Kwangmun K, Hung DM. 2005. Construction of an inter-regional input-output table for Vietnam by the hybrid approach: the case of Hochiminh City and the rest of Vietnam. Presented Paper at the 15th International Conference on Input-Output Techniques, Beijing, China.

http://www.iioa.org/pdf/15th\%20Conf/bui_trinh1.pdf. (accessed 2009/09/15).

Trinh B, Secretario FT, Kwangmun K, Thanh LH, Giang PH. 2008. Economic-environmental impact analysis based on a bi-region interregional I-O model for Vietnam. DEPOCEN Working Paper Series No. 2008/28.

http://depocenwp.org/upload/pubs/BuiTrinh/Economicenvironmental\%20impact\%20anaylysis_DEPOCENWP.pdf. (accessed 2009/09/15). 
UNSTATS. 2009. Available correspondences.

http://unstats.un.org/unsd/cr/registry/regot.asp. (accessed 2009/10/12).

(受付：2011年3月1日，受理：2011年12月6日）

\title{
ベトナムの経済的な活動と水質污染の関係の構造解析
}

\author{
アン ホアン レ 1） 東海明宏 1) 山本祐吾 2)
}

1) 大阪大学大学院工学研究科環境・エネルギー工学専攻 （テ565-0871 大阪府吹田市山田丘2-1）

2) 和歌山大学システム工学部環境システム学科 （テ640-8510 和歌山市栄谷930)

本研究では，ベトナムにおける経済活動から河川への污染物質の排出構造を定量的に評価するため，産業連関表に 基づくモデルを構築した。 2000年の経済活動からのTSS及びBOD排出量を推計した結果，それぞれ356 Mtと43.8 Mt であった．全浮遊固形物（TSS）の主な直接排出セクターは金属工業であり，主な誘発セクターは建設業と金属工業 であった，一方，有機物（BOD）の主な直接排出セクターは農林漁業と飲食料品，夕バコ産業であり，主な誘発セ クターは家計消費と輸出業であった．さらに各経済セクターの污濁物質排出の流れをさらに調査し，環境負荷排出の 誘発構造を描き主要セクターを明らかにした。これらの解析により，優先的に排出削減を進めるべき経済セクターに 関し示唆を得た。

キーワード：ベトナム経済，水質污染，投入産出分析，直接排出，誘導排出，排出成分 